\title{
Reviewers of Articles Submitted in 2021
}

Terry Veling

Australian Catholic University, Australia

Claude Mangion

University of Malta, Malta

Giacchino Curiello

Bishop Grosseteste University, United Kingdom

John Berry

University of Malta, Malta

Niamh Middleton

Dublin City University, Ireland

Francis Jonbäck

University of Uppsala, Sweden

Hector Scerri

University of Malta, Malta

Michael O’Sullivan

Chinese University of Hong Kong, Hong Kong

Joseph Rivera

Dublin City University, Ireland

Rita Fulco

Università degli Studi di Messina, Italy

Deborah Casewell

King's College London, United Kingdom

David Schindler

The Catholic University of America, USA

Irina Poleshchuk

University of Helsinki, Finland

Jan Frei

Archivu Jana Patočky, Czech Republic

Dariusz Bęben

University of Silesia, Poland

Mario Bosincu

Università di Sassari, Italy

Alison Ross

Monash University, Australia

Fiona Ellis

University of Roehampton, United Kingdom

Jussi Backman

University of Helsinki, Finland

Stefan Gandler

Autonomous University of Querétaro, México 
Cristian Ciocan

University of Bucharest, Romania

Piotr Janik

Jesuit University Ignatianum in Krakow, Poland

Jean-Paul De Lucca

University of Malta, Malta

Ulrich Diehl

Universität Heidelberg, Germany

Frank Darwiche

Univeristy of Lebanon, Lebanon

Bence Marosan

Budapest Business School, Hungary

Jose Luis Guzon Nestar

University of Madrid, Spain

José Luis Bermúdez

Texas A\&M University, USA

Wojciech Szczerba

Von Hügel Institute, St Edmund's College, University of Cambridge, United

Kingdom

Ian Alexander Moore

Loyola Marymount University, USA

Jan Eike Dunkhase

Free University of Berlin, Germany

Jean-François Kervegan

Université Paris 1 Panthéon-Sorbonne, France

Tommaso Tuppini

University of Verona, Italy

Till Kinzel

Technische Universität Berlin, Germany

Sergio Sanchez-Migallon

Universidad de Navarra, Spain

Panos Theodorou

University of Crete, Greece

Madgalena Hoły-Łuczaj

University of Information Technology and Management, Poland

Warwick Mules

Southern Cross University, Australia

Piotr Duchliński

Jesuit University Ignatianum in Krakow, Poland

Michael Pakaluk

The Catholic University of America

Jeffrey Andrew Barash

University of Paris, France

Leonard Lawlor

Penn State University, USA 
Andrzej Serafin

Pedagogical University of Krakow, Poland

Semra Ucar

Sinop Üniversitesi, Turkey

Gustavo Aucar

Northwestern University of Argentina, Argentina

Marta Ples-Bęben

University of Silesia, Poland 